\title{
Impact of MEFV genotype in Caucasian children with periodic fever
}

\author{
Silvia Federici ${ }^{*}$, G Calcagno ${ }^{2}$, Martina Finetti ${ }^{1}$, Romina Gallizzi ${ }^{3}$, Antonella Meini ${ }^{4}$, A Vitale ${ }^{2}$, F Caroli ${ }^{5}$, M Cattalini $^{4}$, \\ Roberta Caorsi ${ }^{1}$, Francesco Zulian ${ }^{6}$, Alberto Tomasini ${ }^{7}$, A Insalaco $^{8}$, J Frenkel ${ }^{9}$, Mariapia Sormani ${ }^{10}$, M Baldi $^{6}$, \\ Isabella Ceccherini ${ }^{5}$, Alberto Martini ${ }^{1}$, Marco Gattorno ${ }^{1}$
}

From 18th Pediatric Rheumatology European Society (PReS) Congress

Bruges, Belgium. 14-18 September 2011

\section{Introduction}

Despite FMF is considered an autosomal recessive disease caused by mutations of $M E F V$, one third of patients carries one mutation only.

\section{Aim}

To analyze the actual impact of MEFV mutations in children with periodic fever.

\section{Methods}

113 caucasian patients carrying MEFV mutations (46 with mutations in two alleles, 67 heterozygous) and 205 genetically negative patients for MEFV, TNFSF1A and MEFV (70\% with a PFAPA phenotype) were analyzed. The fol- lowing groups were considerd: patients with: i) 2 high penetrance mutations (M694V, M694I, M680I), ii) 1 high, 1 low penetrance mutation, iii) 2 low penetrance mutations, iv) 1 high penetrance mutation, v) one low penetrance mutation, vi) genetically negative.

\section{Results}

Patients with two mutations displayed a higher prevalence of chest pain $(p=0.001)$, pleurisy $(p=0.003)$ and severe abdominal pain $(p=0.002)$ in respect to heterozygous patients, which clinical phenotype was more similar to that presented by genetically negative patients, with an higher prevalence of erythematous $(p=0.01)$ and exudative $(\mathrm{p}=0.009)$ pharyngitis, enlarged cervical

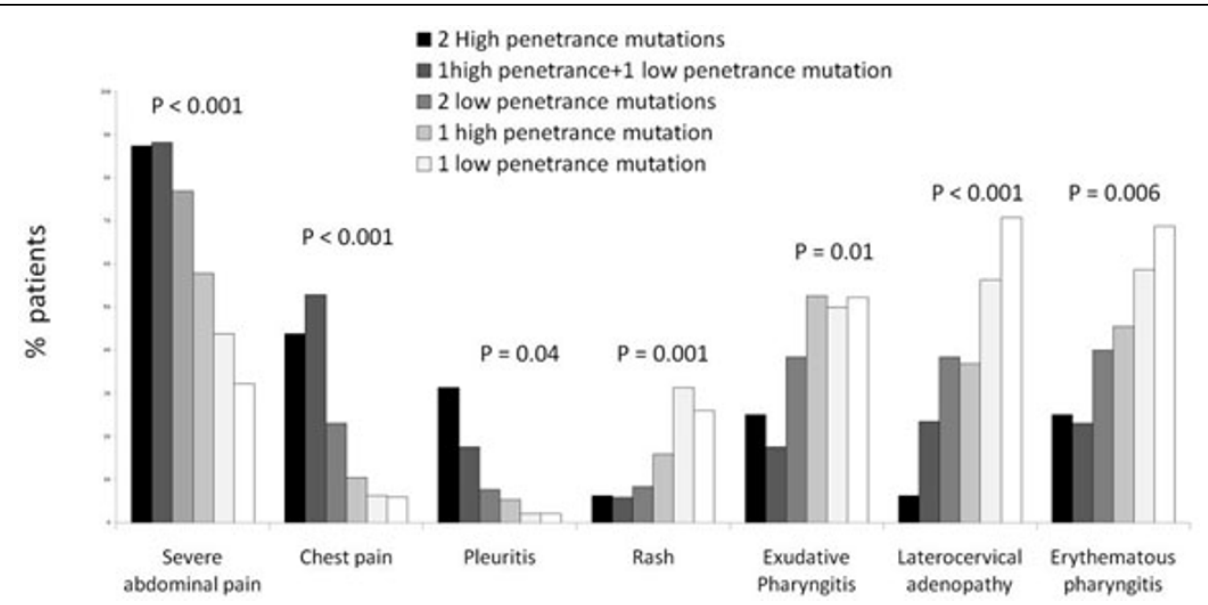

Figure 1 Prevalence of the clincial manifestations associated to fever attacks in patients with different MEFV genotypes (see text) and in patients with periodic fever negative for mutations of MEFV, MVK and TNFSRF1A genes. P values were assessed by a Chi-square test for trend.

${ }^{1}$ Gaslini Institute, Genova, Italy

Full list of author information is available at the end of the article

(c) 2011 Federici et al; licensee BioMed Central Ltd. This is an open access article distributed under the terms of the Creative Commons B. Wed Central Attribution License (http://creativecommons.org/licenses/by/2.0), which permits unrestricted use, distribution, and reproduction in any medium, provided the original work is properly cited. 
lymph nodes $(\mathrm{p}=0.002)$. The frequency of "FMF-like symptoms" decreases from patients carrying two high penetrance mutations towards patients with a single low penetrance mutation with a specular increase of "PFAPA-like symptoms" (Figure 1).

\section{Conclusions}

The present study shows a dosage effect of MEFV mutations not consistent with a pure autosomal recessive disorder. A dominant negative or gain of function effects or variants of still unidentified modifier genes may influence the presence of a FMF phenotype in heterozygous patients.

\section{Author details}

${ }^{1}$ Gaslini Institute, Genova, Italy. ${ }^{2}$ Sezione di Reumatologia Pediatrica, AOU "G. Martino ", Messina, Italy. ${ }^{3}$ Divisione di Immunologia e Reumatologia Pediatrica, università di Messina, Messina, Italy. ${ }^{4}$ Dipartimento di Pediatria, Unità di Immunologia e Reumatologia Pediatrica, Spedali Civili E University Of Brescia, Italy. ${ }^{5}$ Laboratorio di Genetica Molecolare,Gaslini Institute, Genova, Italy. ${ }^{6}$ Dipartimento A.I. di Pediatria,University of Padua, Padova, Italy. ${ }^{7}$ IRCCS Burlo Garofolo, Dipartimento di Pediatria, University of Trieste, Trieste, Italy. ${ }^{8}$ Divisione di Reumatologia, Ospedale Pediatrico Bambino Gesù, IRCCS,

Roma, Italy. 'Department of Pediatrics,Wilhelmina Children's Hospital, University Medical Center, Utrecht, The Netherlands. ${ }^{10}$ Unità di Biostatistica, DISSAL, University of Genoa, Genova, Italy.

Published: 14 September 2011

\section{doi:10.1186/1546-0096-9-S1-P302}

Cite this article as: Federici et al:: Impact of MEFV genotype in

Caucasian children with periodic fever. Pediatric Rheumatology 20119

(Suppl 1):P302.

\section{Submit your next manuscript to BioMed Central} and take full advantage of:

- Convenient online submission

- Thorough peer review

- No space constraints or color figure charges

- Immediate publication on acceptance

- Inclusion in PubMed, CAS, Scopus and Google Scholar

- Research which is freely available for redistribution

Submit your manuscript at www.biomedcentral.com/submit 